Article

\title{
The Impact of Cloud Radiative Effects on the Tropical Tropopause Layer Temperatures
}

\author{
Qiang Fu ${ }^{1, *}$, Maxwell Smith ${ }^{1}$ and Qiong Yang ${ }^{2,3}$ \\ 1 Department of Atmospheric Sciences, University of Washington, Seattle, WA 98195, USA; \\ maxwell.a.smith@gmail.com \\ 2 Joint Institute for the Study of the Atmosphere and Ocean, University of Washington, \\ Seattle, WA 98195, USA; qyangrad@gmail.com \\ 3 Pacific Marine Environmental Laboratory, National Oceanic and Atmospheric Administration, \\ Seattle, WA 98115, USA \\ * Correspondence: qfu@atmos.washington.edu
}

Received: 22 August 2018; Accepted: 26 September 2018; Published: 28 September 2018

\begin{abstract}
A single-column radiative-convective model ( $\mathrm{RCM}$ ) is a useful tool to investigate the physical processes that determine the tropical tropopause layer (TTL) temperature structures. Previous studies on the TTL using the RCMs, however, omitted the cloud radiative effects. In this study, we examine the impact of cloud radiative effects on the simulated TTL temperatures using an RCM. We derive the cloud radiative effects based on satellite observations, which show heating rates in the troposphere but cooling rates in the stratosphere. We find that the cloud radiative effect warms the TTL by as much as $2 \mathrm{~K}$ but cools the lower stratosphere by as much as $-1.5 \mathrm{~K}$, resulting in a thicker TTL. With (without) considering cloud radiative effects, we obtain a convection top of $\approx 167 \mathrm{hPa}(\approx 150 \mathrm{hPa})$ with a temperature of $\approx 213 \mathrm{~K}(\approx 209 \mathrm{~K})$, and a cold point at $\approx 87 \mathrm{hPa}(\approx 94 \mathrm{hPa})$ with a temperature of $\approx 204 \mathrm{~K}(\approx 204 \mathrm{~K})$. Therefore, the cloud radiative effects widen the TTL by both lowering the convection-top height and enhancing the cold-point height. We also examine the impact of TTL cirrus radiative effects on the RCM-simulated temperatures. We find that the TTL cirrus warms the TTL with a maximum temperature increase of $\approx 1.3 \mathrm{~K}$ near $110 \mathrm{hPa}$.
\end{abstract}

Keywords: tropical tropopause layer; cloud radiative effects; temperature structure

\section{Introduction}

The tropical tropopause layer (TTL), ranging from $\approx 14.5 \mathrm{~km}$ to $18.5 \mathrm{~km}$, is a transition layer between the troposphere and stratosphere and has both tropospheric and stratospheric characteristics [1-6]. Since air enters the stratosphere preferentially through upwelling in the TTL, the TTL exerts important controls over the stratospheric composition and global climate [6-9]. For example, the water vapor amount in the tropical lower stratosphere is largely determined by the cold TTL temperatures through the dehydration that dries the upwelling air [6,10-13]. In view of the importance of the TTL for the climate system, it is important to understand the physical processes that govern the TTL temperature structures, which include dynamics on a vast range of scales, radiation, and clouds.

A single-column radiative-convective model (RCM) is a useful tool as an essentially correct first approximation to investigate the physical processes that determine the TTL structure and its sensitivities to constituents and dynamical cooling associated with large-scale ascent [14-16]. In the RCM framework, the TTL is defined as the layer between the cold-point tropopause (i.e., the coldest point in the temperature profile) and the top of the convection. The RCMs are indeed able to capture the fact that the cold-point tropopause is several kilometers above the convectively adjusted region $[14,17,18]$, indicating a cold point decoupled from convection due to radiative processes. 
Thuburn and Craig [14] suggested that a localized heating in the $15 \mu \mathrm{m} \mathrm{CO}$ band, owing to the sharp curvature in the temperature profile near the convection top, forces apart the cold point and convection top. Birner [15] examined a stratospheric radiative equilibrium solution by prescribing a tropospheric temperature profile. He found that the separation of the top of the convection and the tropopause in the tropics (i.e., the existence of the TTL) is almost entirely due to stratospheric dynamics. Recently, Birner and Charlesworth [16] investigated the role of water vapor and ozone radiative heating on the detailed temperature structure of the TTL based on the RCM simulations. It was shown that adiabatic cooling due to upwelling reduces the radiative control by water vapor, resulting in a negative transport-radiation feedback while the radiative control by ozone is enhanced due to upwelling, i.e., a positive transport-radiation feedback. All previous studies on the TTL using the RCMs, however, omitted the cloud radiative effects [14-16].

Cloud radiative effects play an important role in the TTL radiative energy budget, largely through the anvil clouds associated with the convective outflow between about 10 and $15 \mathrm{~km}$, and thin cirrus clouds driven by the large-scale vertical motion between $\approx 14.5$ to $17 \mathrm{~km}$ [19-22]. Here we examine the impact of cloud radiative effects on the simulated TTL temperatures using an RCM. Consistent with the previous studies [14,16-18], a cold-point tropopause is well separated from the convectively adjusted regions in our RCM simulations even without considering the dynamic cooling associated with the large-scale ascent. In contrast to Thuburn and Craig [14], however, we find that the TTL does not owe its existence to the $\mathrm{CO}_{2}$ radiative effects. We further show that the cloud radiative effect leads to a lower top of the convectively adjusted region but a higher cold-point tropopause, resulting in an increase in the TTL thickness. Section 2 presents the cloud radiative effects derived from observations and Section 3 describes the RCM used in this study and compares the simulations with Thuburn and Craig [14]. The impact of cloud radiative effects on simulated TTL temperatures is shown in Section 4, and a summary is given in Section 5 .

\section{Cloud Radiative Effects in Tropics}

We derived the cloud radiative effect, which is defined as the difference between radiative heating rate profiles in whole sky and those in clear sky, for each $2.5^{\circ} \times 2.5^{\circ}$ grid box over the tropics and for each month from June 2006 to May 2007 based on observations.

Collocated cloud fields from satellite observations including Cloud-Aerosol Lidar and Infrared Pathfinder Satellite Observation (CALIPSO), CloudSat, and a Moderate Resolution Imaging Spectroradiometer (MODIS) onboard the Aqua satellite were used. CALIPSO lidar can detect optically-thin cirrus clouds that prevail in the TTL but the lidar signal becomes attenuated when cloud optical depth is larger than $\approx 3.0-4.0$ [23,24]. We used the CALIPSO level 2 version $35 \mathrm{~km}$ cloud and aerosol layer products. The clouds included in the aerosol layer product as so-called "stratospheric features" were considered here by separating clouds from aerosols following Tseng and $\mathrm{Fu}$ [25]. For cloud layers that the CALIPSO lidar could penetrate, we used cloud top and cloud base heights from CALIPSO. Cloud optical depth was retrieved following Yang et al. [21] but using an updated effective lidar ratio of $18 \mathrm{sr}$ for ice clouds. Within a given cloud layer, a homogenous vertical distribution of the cloud extinction coefficient and a generalized particle size of $30 \mu \mathrm{m}$ were assumed [21]. Given a cloud optical depth, the derived cloud radiative effect was not sensitive to the assumed ice particle size. The collocated MODIS (version 6) and CALIPSO cloud optical depths agreed well by examining cloud columns that CALIPSO could penetrate with an average difference of less than $20 \%$. For optically thick clouds that CALIPSO could not penetrate, we used the collocated CloudSat cloud geometric heights and vertical profiles of ice and liquid water content scaled by the MODIS cloud optical depth. We employed the CloudSat 2B-CWC-RO dataset [26] and MODIS level 2 MYD 06 cloud product version 6 [27]. Noting that the MODIS gave the total cloud optical depth for the whole column, the optical depth for the opaque clouds was obtained by subtracting the total non-opaque cloud optical depth detected using CALIPSO from the MODIS observation as $\tau_{\text {opaque }}=\tau_{\text {MODIS }}-\sum_{\text {non-opaque }} \tau_{\text {CALIPSO, where }} \tau_{\text {MODIS }}$ is the MODIS observed total column cloud 
optical depth and $\sum_{\text {non-opaque }} \tau_{\text {CALIPSO }}$ is the summation of the cloud optical depths retrieved from CALIPSO for the non-opaque cloud layers above the opaque cloud layers. We then used $\tau_{\text {opaque }}$ to scale the profiles of cloud water content from CloudSat. Here the vertical distributions of cloud particle sizes were derived based on cloud water content according to Heymsfield et al. [28] for ice clouds and Fueglistaler and $\mathrm{Fu}[29]$ for water clouds.

To derive the cloud radiative heating based on observations, monthly mean vertical profiles of temperature, water vapor mixing ratio, and ozone mixing ratio were obtained from the ERA-Interim gridded atmospheric reanalysis [30]. However, the coarse vertical resolution around the tropical tropopause had limited the ability of the temperature profile from the ERA-Interim to resolve a realistic cold-point tropopause temperature, which is essential to obtain accurate radiative heating rates in the TTL where the radiative relaxation time is long [31]. The COSMIC uses the GPS Radio Occultation (RO) limb-sounding technique for sounding the Earth's atmosphere from satellites [32,33]. It has the advantages of high accuracy in the upper troposphere and lower stratosphere [34-36] with a high vertical resolution [37]. COSMIC temperature profiles from June 2006 to May 2007 were obtained from the COSMIC Data Analysis and Archive Center (CDAAC). For each grid box and month, the ERA-Interim and COSMIC temperature profiles were blended as:

$$
\mathrm{T}_{\text {blend }- \text { in }}=\left\{\begin{array}{lc}
\mathrm{W} \cdot \mathrm{T}_{\text {ERA }}+(1-\mathrm{W}) \cdot \mathrm{T}_{\text {COSMIC }} & 70-50 \mathrm{hPa} \\
\mathrm{T}_{\text {COSMIC }} & 100-70 \mathrm{hPa} \\
(1-\mathrm{W}) \cdot \mathrm{T}_{\text {ERA }}+\mathrm{W} \cdot \mathrm{T}_{\text {COSMIC }} & 125-100 \mathrm{hPa}
\end{array}\right.
$$

where weighting function $\mathrm{W}$ linearly increases from 0 to 1 within each layer, $\mathrm{T}_{\mathrm{ERA}}$ and $\mathrm{T}_{\mathrm{COSMIC}}$ are the ERA-Interim and COSMIC temperature profile, respectively, and $\mathrm{T}_{\text {blend-in }}$ is the blended temperature (see Figure 1 as an example). For water vapor and ozone profiles from ERA-Interim, we applied a cubic spline interpolation to avoid abrupt jumps near the cold-point tropopause. All atmospheric profiles were interpolated into a finer vertical resolution of $\approx 100$ meter in the TTL following Yang et al. [21].

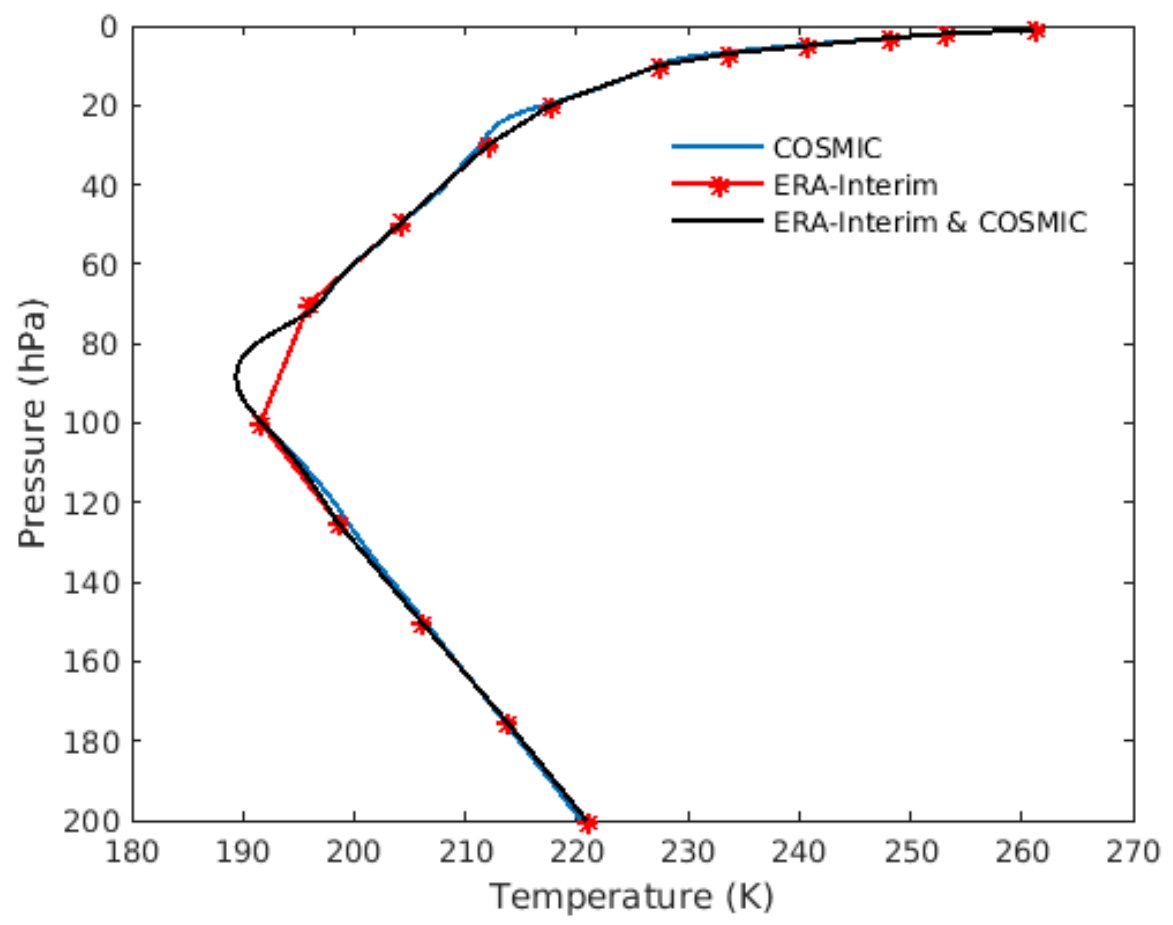

Figure 1. An example of the merged temperature profile (black) from the ERA-Interim (red) and COSMIC (blue) temperature profiles. 
The NASA Langley Fu-Liou radiation model [38-45] was used to calculate radiative heating rates. A delta-four stream approach for the radiative transfer was used for the shortwave while a delta-two and four stream combination was used for the longwave [39,41,46]. The correlated k-distribution method was used to parameterize the non-gray gaseous absorption by $\mathrm{H}_{2} \mathrm{O}, \mathrm{CO}_{2}, \mathrm{O}_{3}$, $\mathrm{N}_{2} \mathrm{O}$, and $\mathrm{CH}_{4}$ [38]. A treatment of CFCs was included in the 8-12 $\mu$ m window region [43]. $\mathrm{Th} \mathrm{H}_{2} \mathrm{O}$ continuum absorption was included in the whole thermal infrared spectra following the CKD 2.4 [47]. For ice clouds, the single scattering properties, including the extinction coefficient, single-scattering albedo, and asymmetry factor, were parameterized with ice water content and generalized effective particle size [40,42]. For water clouds, the single scattering properties were parameterized based on Mie calculations using liquid water content and mean effective radius. Monthly and latitudinal dependence of solar insolation and the diurnal variation of solar radiation were taken into account explicitly.

We calculated the cloud radiative effects for all cloud profiles detected using the CALIPSO combined with CloudSat and MODIS for a given month and over a given $2.5^{\circ} \times 2.5^{\circ}$ grid box. We then averaged them to obtain the monthly mean cloud radiative effect over each grid box, from which we derived the annual mean cloud radiative effects averaged over the tropics.

Figure 2 (left) shows the cloud radiative effects averaged over $20^{\circ} \mathrm{N}-20^{\circ} \mathrm{S}$ (solid line) and western Pacific $\left(15^{\circ} \mathrm{N}-15^{\circ} \mathrm{S}, 120^{\circ} \mathrm{E}-180^{\circ} \mathrm{E}\right)$ (dashed line). The cloud radiative effects were positive throughout the troposphere except near the surface. The three maxima in the cloud radiative effects near $800-900 \mathrm{hPa}, 550 \mathrm{hPa}$, and $200-300 \mathrm{hPa}$ were in line with the trimodal structure of tropical clouds [48-50]. The maximum heating rates near 200-300 hPa were $0.5 \mathrm{~K} /$ day over the tropics and $0.95 \mathrm{~K} /$ day over the western Pacific. The cooling effects of clouds in the lower stratosphere above $\approx 90 \mathrm{hPa}$ level were also seen in Fueglistaler and $\mathrm{Fu}$ [29]. The cloud radiative effects over the western Pacific were about twice of those averaged over $20^{\circ} \mathrm{N}-20^{\circ}$ S. Figure 2 (right) shows the cloud radiative effects of TTL cirrus, which was derived as the difference of the radiative heating rates for the whole skies with and without the TTL cirrus. The TTL cirrus is clouds with cloud base height higher than $14.5 \mathrm{~km}[51,52]$. The TTL cirrus introduces heating in the TTL, with a maximum heating of $0.09 \mathrm{~K} /$ day $(0.17 \mathrm{~K} /$ day) near $110 \mathrm{hPa}$ over the tropics (western Pacific). The impact of the cloud radiative effects shown in Figure 2 on the TTL temperatures are presented in Section 4.
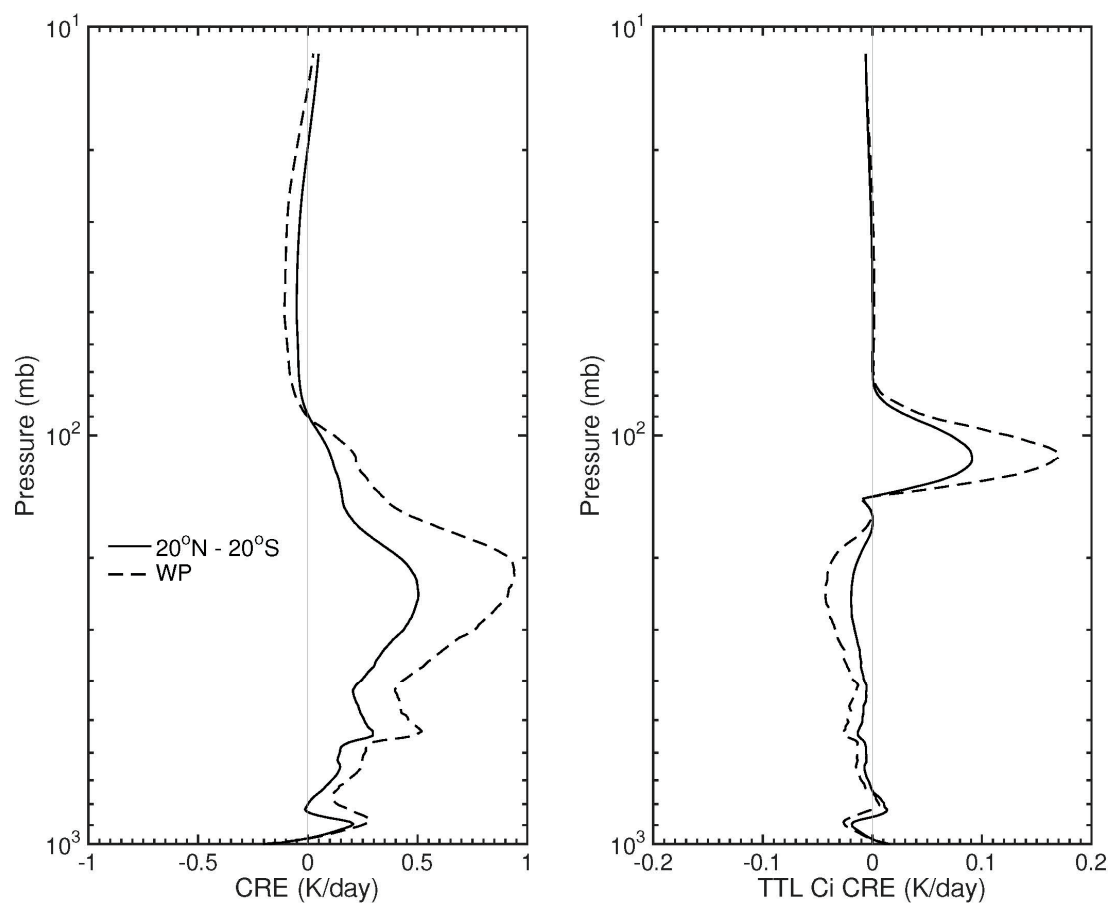

Figure 2. (Left) Cloud radiative effect (CRE) over the tropics (solid) and western Pacific (dashed). (Right) The same as left but for the TTL cirrus cloud radiative effect. 


\section{Radiative-Convective Model and Simulations}

The radiative-convective model used here closely follows that in Thuburn and Craig [14] for a comparison purpose but using different radiation schemes. Thuburn and Craig [14] employed the broadband radiation scheme developed by Morcrette [53] and Zhong and Haigh [54] and Zhong et al. [55]. Here we use the NASA Langley Fu-Liou radiation model to calculate the radiative heating rates. We also used the rapid radiative transfer model (RRTM) [56,57]. Since they produce very similar results, we only show results from the RCM with the NASA Langley-Fu-Liou radiation scheme. The vertical domain of the RCM was from $1013 \mathrm{hPa}$ to $0.01 \mathrm{hPa}$. An equal logarithmic spacing was used for 601 levels. The radiation heating rates were calculated for the entire domain to adjust the temperature. We only analyzed the results below $10 \mathrm{hPa}$ when the simulated temperatures reached equilibrium for all altitudes below a $10 \mathrm{hPa}$ level. We use a solar constant of $1361 \mathrm{Wm}^{-2}$, a mean solar zenith angle of $50.5^{\circ}$, and a daytime fraction of 0.5 .

The ozone profile used was that found in Yang et al. [58], Yang et al. [21], and Lin et al. [22], taken from the SHADOZ observations [59], with data above $0.2 \mathrm{hPa}$ obtained from the HALOE $[4,60]$. Similar results were obtained by using a standard tropical ozone profile [61]. The $\mathrm{CO}_{2}, \mathrm{CH}_{4}$, and $\mathrm{N}_{2} \mathrm{O}$ were assumed to be well-mixed with a concentration of $356 \mathrm{ppmv}, 1.7 \mathrm{ppmv}$, and $0.28 \mathrm{ppmv}$, respectively. Following Thuburn and Craig [14], the water vapor profile was determined at each time step with a fixed relative humidity $(R H)$ of $50 \%$, subject to the constraint that the water vapor mixing ratio may not increase with altitude. Thus, there was a constant $R H$ in the troposphere but a constant mixing ratio that begins from the temperature minimum level and extends through the stratosphere.

Following Thuburn and Craig [14], the surface temperature Ts and the tropospheric lapse rate $\gamma$ are specified as $300 \mathrm{~K}$ and $6.5 \mathrm{~K} / \mathrm{km}$, respectively, in the RCM. At each time step, if the temperature at altitude $z$ fell below $T s-\gamma z$, then it was reset to equal $T s-\gamma z$. The model was integrated in time from an arbitrary initial condition until equilibrium was reached. At each time step, we calculated the water vapor profile, updated temperatures with the calculated radiative heating rates, and then applied the convective adjustment. The temperature profile in the convectively adjusted region was thus fixed by the imposed parameters while the top of the convectively adjusted region and the radiative equilibrium profile above were determined by the RCM [14].

In our control simulations using an $\mathrm{RH}$ of $50 \%$ and $\mathrm{CO}_{2}$ concentration of $356 \mathrm{ppmv}$, we obtained a convection top of $\approx 150 \mathrm{hPa}$ with a temperature of $\approx 209 \mathrm{~K}$ and a cold point at $\approx 95 \mathrm{hPa}$ with a temperature of $\approx 204 \mathrm{~K}$. For comparison, Thuburn and Craig [14] obtained the convection top at $145 \mathrm{hPa}$ and at a temperature of $211.4 \mathrm{~K}$, and the cold point at $105 \mathrm{hPa}$ and a temperature of $206.9 \mathrm{~K}$. The small differences may be caused by the different ozone profiles used and the different radiation models used, as well as the differences in some details in the RCMs. As in Thuburn and Craig [14], our RCM in radiative equilibrium produced a TTL layer that separated the cold point from the top of the convectively-adjusted region.

For a further comparison with results from Thuburn and Craig [14], we repeated their sensitivity study to $R H$ by changing the $R H$ from $1 \%$ to $90 \%$ (keeping all other parameters the same as in the control experiment) (Figure 3). Our results were very similar to those from Thuburn and Craig [14] (see their Figure 7), if not identical. Figure 3 shows that the cold point height was insensitive to the $R H$ but the convection-top height increased with the $R H$. Both temperatures at the cold point and top of the convective region decreased with the $R H$. 

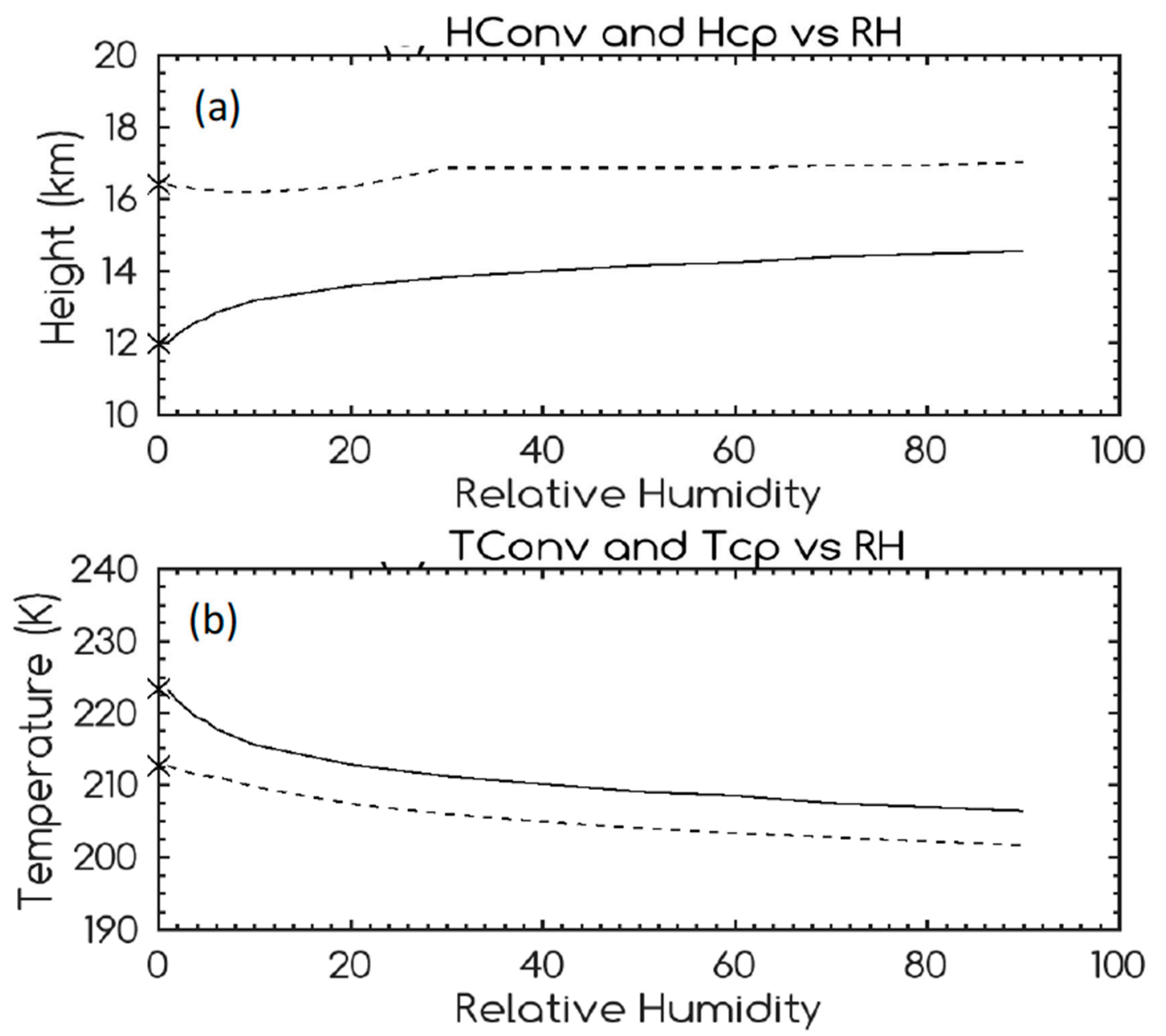

Figure 3. (a) Dependence of the convection-top height (solid) and the cold-point height (dashed) on the relative humidity. (b) Dependence of the convection-top temperature (solid) and the cold-point temperature (dashed) on the relative humidity.

We also carried out the sensitivity runs to carbon dioxide concentration following Thuburn and Craig [14]. Here we changed the $\mathrm{CO}_{2}$ mixing ratio from the 356 ppmv value by multiplying a factor ranging from 0 to 10 . Figure 4 shows the height (Figure $4 \mathrm{a}$ ) and temperature (Figure $4 \mathrm{~b}$ ) of the cold point and the convection top versus the carbon dioxide factor $(f)$. The symbol " $X$ " represents the equilibrium states for $f=0$. Different from Thuburn and Craig [14], the separation of the cold point and convection top (i.e., the existence of the TTL) was always seen regardless of the $\mathrm{CO}_{2}$ concentrations. For $f=0$ (i.e., a zero $\mathrm{CO}_{2}$ concentration), the separation was still about $0.7 \mathrm{~km}$ and $1.1 \mathrm{~K}$ (Figure 4). It is worth noting that we also obtained a separation of $0.7 \mathrm{~km}$ and $1.0 \mathrm{~K}$ using the RRTM in the RCM. Therefore, our results indicated that in contrast to Thuburn and Craig [14], the separation of the cold point and the convective top was not due to the $\mathrm{CO}_{2}$ radiative effects. The dependences of the height and temperature of the cold point and the convection top on the carbon dioxide concentration (Figure 4) were also somewhat different from those shown in Thuburn and Craig [14] (see their Figure 5). For example, the convection-top height was insensitive to the $\mathrm{CO}_{2}$ factor in our simulations, while it decreased with the $\mathrm{CO}_{2}$ factor in Thuburn and Craig [14]. When $f<0.2$, the cold-point height increased with $f$ in our simulations, while the dependence from Thuburn and Craig [14] was not monotonic. In addition, the temperature of the cold point and the convection top was less sensitive to the $\mathrm{CO}_{2}$ factor in our simulations as compared with Thuburn and Craig [14], who showed a steady increase with the $\mathrm{CO}_{2}$ mixing ratio for $f<0.2$. We believe that the differences between the present results and those from Thuburn and Craig [14] are largely associated with the different radiation 
models used. We have more confidence in our results since we obtained similar results using two different modern radiation models. It is interesting to notice that both our simulations and those from Thuburn and Craig [14] show that the height and temperature of the cold point and the convection top had little dependence on the carbon dioxide concentration when $f>0.2$. Furthermore, these two studies show similar separations in both height and temperatures, which are about $2.5 \mathrm{~km}$ and $4.5 \mathrm{~K}$, respectively, when $f>0.2$.

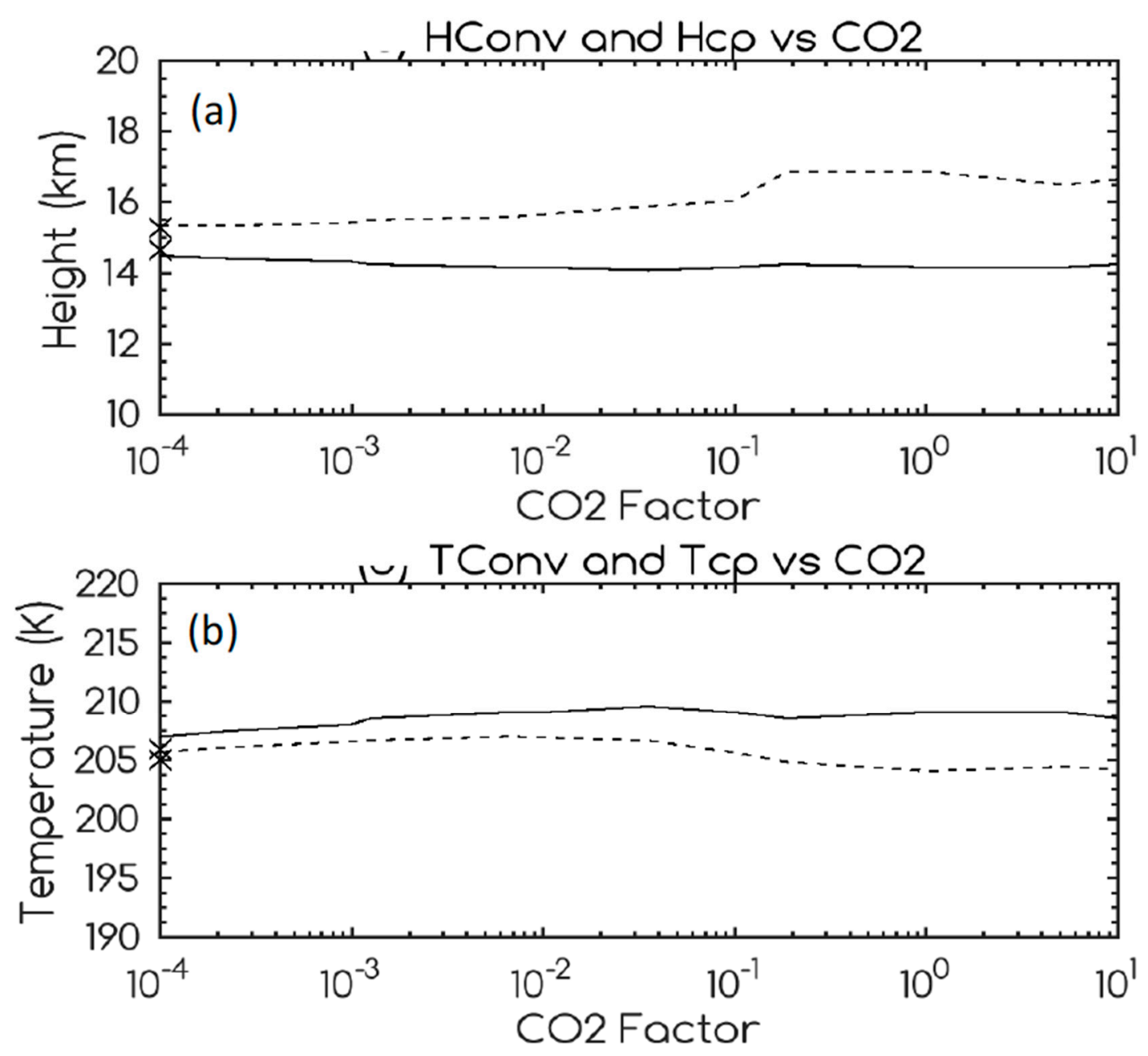

Figure 4. (a) Dependence of the convection-top height (solid) and the cold-point height (dashed) on the carbon dioxide scaling factor. (b) Dependence of the convection-top temperature (solid) and the cold-point temperature (dashed) on the carbon dioxide scaling factor. The " $\mathrm{X}$ " symbols represent the states for $f=0$ (i.e., zero $\mathrm{CO}_{2}$ mixing ratio).

\section{Impact of Cloud Radiative Effects}

The cloud radiative effects derived from observations (Figure 2) were used to examine their impact on the TTL temperature structures in the RCM simulations. The cloud radiative effects were thus considered in our radiative-convective model as a fixed heating rate profile. That is, at each time step, the total radiative heating rates used to update the temperatures were that from the radiation model for the clear-sky condition plus the fixed cloud radiative effects.

Figure 5 (left) shows the temperature profiles simulated from the RCM with (red) and without (blue) considering the cloud radiative effects and Figure 5 (right) shows their differences. The cloud radiative effect warmed the TTL (by as much as $2 \mathrm{~K}$ near $130 \mathrm{hPa}$ ) but cooled the lower stratosphere (by as much as $-1.5 \mathrm{~K}$ ), which led to a thicker TTL. With (without) considering cloud radiative effects, we obtained a convection top of $\approx 167 \mathrm{hPa}(\approx 150 \mathrm{hPa})$ with a temperature of $\approx 213 \mathrm{~K}(\approx 209 \mathrm{~K})$, and a cold point at 
$\approx 87 \mathrm{hPa}(\approx 94 \mathrm{hPa})$ with a temperature of $\approx 204 \mathrm{~K}(\approx 204 \mathrm{~K})$. Therefore, the cloud radiative effects deepened the TTL by both lowering the convection-top height and enhancing the cold point height.
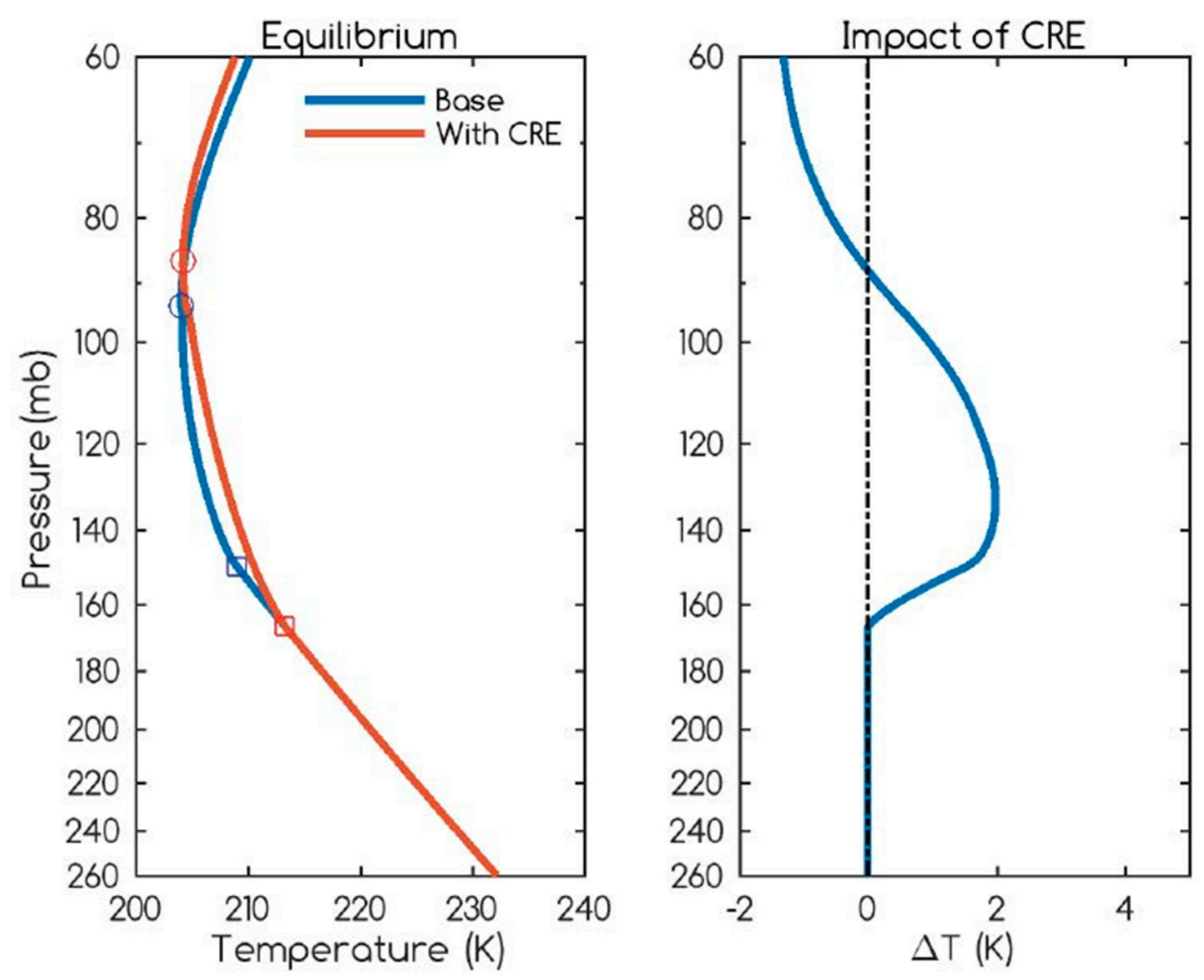

Figure 5. (Left) Equilibrium temperature profiles from the radiative-convective model with (red) and without (blue) cloud radiative effects over the tropics $\left(20^{\circ} \mathrm{N}-20^{\circ} \mathrm{S}\right)$. The square symbols indicate the top of convection. Circles indicate the cold point. (Right) Impact of CRE at the equilibrium temperature.

Figure 6 is the same as Figure 5 but using the cloud radiative effect over the western Pacific. Because of a significantly larger cloud radiative effect over the western Pacific than the tropical mean (Figure 2), the TTL was warmed by more than $4 \mathrm{~K}$ near $140 \mathrm{hPa}$ but cooled by more than $2 \mathrm{~K}$ in the lower stratosphere (Figure 6 right). Using the cloud radiative effect over the western Pacific, we obtained a convection top of $\approx 250 \mathrm{hPa}$ with a temperature of $\approx 230 \mathrm{~K}$, and a cold point at $\approx 82 \mathrm{hPa}$ with a temperature of $\approx 204 \mathrm{~K}$. 

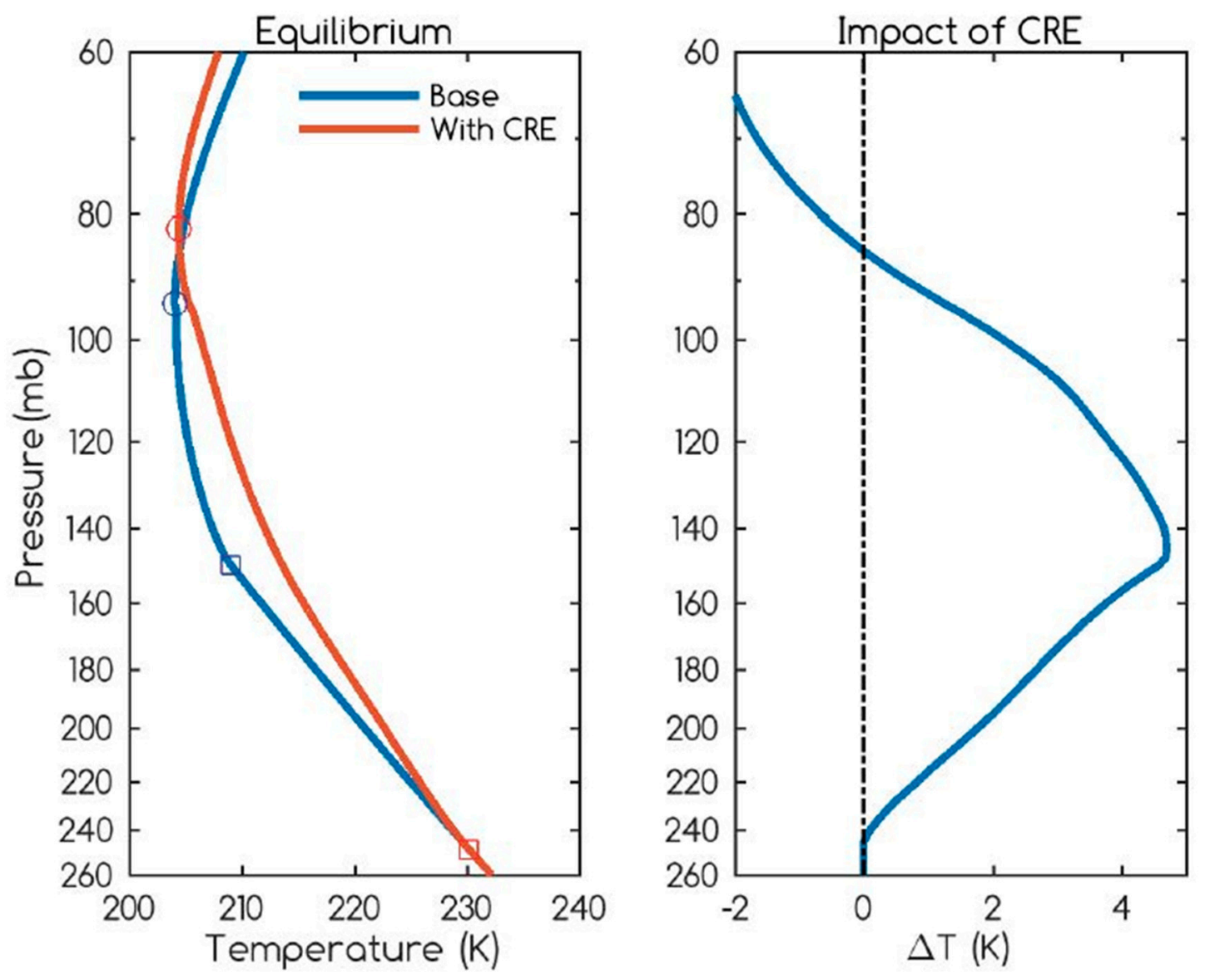

Figure 6. As in Figure 5 but over the western Pacific.

It should be noted that the cloud radiative effects were closely coupled with the convection, which was not considered in our RCM by using a fixed cloud radiative effect profile. For a tropical region with strong convection (e.g., over the western Pacific), we expected a higher convective top. However, this effect was partly compensated by the larger cloud radiative effect that led to a lower convective top (Figure 6). Thus, the cloud radiative effect had a negative feedback to the convection top. The relative role of these two effects could not be addressed using the RCM but can be investigated with a cloud-resolving model that explicitly considers the coupling of convection, clouds, and radiation by prescribing $T s$ but using various large-scale forcings to control the strength of the convection.

With a weak Coriolis force in the tropics, the direct response to a diabatic heating anomaly was mainly the vertical advection instead of a local temperature change. The temperature response necessary to balance the cloud radiative effects, which was through a modification of longwave radiative heating, would be observed over the entire domain [62]. Thus, it was reasonable to use a column model to determine the tropical average temperature response to the tropical average radiative heating perturbation. However, the interpretation of the response to the cloud radiative effects only over the western Pacific (Figure 6) should be done with caution in addition to a sensitivity of the response to different cloud radiative effects.

We also examined the impact of TTL cirrus radiative effects on the RCM-simulated temperatures. The TTL cirrus warmed the TTL with a maximum temperature increase of $\approx 1.3 \mathrm{~K}(\approx 2.5 \mathrm{~K})$ near $110 \mathrm{hPa}$ over the tropics (the western Pacific). Most of the impact of cloud radiative effects on temperatures near $110 \mathrm{hPa}$ was caused by the TTL cirrus clouds. 


\section{Summary and Conclusions}

A single-column radiative-convective model (RCM) was used to investigate the physical processes that determine the tropical tropopause layer (TTL) temperature structures. Consistent with previous studies, our RCM simulated the cold-point tropopause that is several kilometers above the convectively adjusted region, indicating a cold point decoupled from convection due to radiative processes. In contrast to a previous study, however, we found that the TTL did not owe its existence to the $\mathrm{CO}_{2}$ radiative effects.

Cloud radiative effects played an important role in the TTL radiative energy budget. However, previous studies on the TTL using the RCMs all omitted the cloud radiative effects. In this study, we examined the impact of cloud radiative effects on the simulated TTL temperatures using an RCM. We derived the cloud radiative effects based on satellite observations, which showed heating rates in the troposphere but cooling rates in the stratosphere.

We found that the cloud radiative effect warmed the TTL by as much as $2 \mathrm{~K}$ but cooled the lower stratosphere by as much as $-1.5 \mathrm{~K}$, resulting in a thicker TTL. With (without) considering cloud radiative effects, we obtained a convection top of $\approx 167 \mathrm{hPa}(\approx 150 \mathrm{hPa})$ with a temperature of $\approx 213 \mathrm{~K}(\approx 209 \mathrm{~K})$, and a cold point at $\approx 87 \mathrm{hPa}(\approx 94 \mathrm{hPa})$ with a temperature of $\approx 204 \mathrm{~K}(\approx 204 \mathrm{~K})$. Therefore, the cloud radiative effects widened the TTL by both lowering the convection-top height and enhancing the cold-point height. We also examined the impact of TTL cirrus radiative effects on the RCM-simulated temperatures. We found that the TTL cirrus warmed the TTL with a maximum temperature increase of $\approx 1.3 \mathrm{~K}$ near $110 \mathrm{hPa}$.

Author Contributions: Q.F. conceived and designed the study; M.S. performed the RCM simulations and Q.Y. performed the analysis of cloud radiative effects; Q.F. wrote the paper; M.S. and Q.Y. prepared the figures.

Funding: This research was supported by the NASA grants 80NSSC18K1031 and NNX16AO95G, NSF grant AGS-1821437, and the Office of Science (BER), U.S. Department of Energy under Grant DE-SC0018190. Q. Yang is partly funded by JISAO under NOAA Cooperative Agreement and NA15OAR4320063, Contribution No. 2018-0167 and contribution \#4829 to PMEL.

Acknowledgments: All sources of funding of the study should be disclosed. Please clearly indicate grants that you have received in support of your research work. Clearly state if you received funds for covering the costs to publish in open access.

Conflicts of Interest: The authors declare no conflict of interest.

\section{References}

1. Highwood, E.J.; Hoskins, B.J. The tropical tropopause. Q. J. R. Meteorol. Soc. 1998, 124, 1579-1604. [CrossRef]

2. Folkins, I.; Loewenstein, M.; Podolske, J.; Oltmans, S.J.; Proffitt, M. A barrier to vertical mixing at 14 km in the tropics: Evidence from ozonesondes and aircraft measurements. J. Geophys. Res. Atmos. 1999, 104, 22095-22102. [CrossRef]

3. Holton, J.R.; Gettelman, A. Horizontal transport and the dehydration of the stratosphere. Geophys. Res. Lett. 2001, 28, 2799-2802. [CrossRef]

4. Gettelman, A.; de Forster, P.M.; Fujiwara, M.; Fu, Q.; Vömel, H.; Gohar, L.K.; Johanson, C.; Ammerman, M. Radiation balance of the tropical tropopause layer. J. Geophys. Res. 2004, 109, 7103. [CrossRef]

5. Fu, Q.; Hu, Y.; Yang, Q. Identifying the top of the tropical tropopause layer from vertical mass flux analysis and CALIPSO lidar cloud observations. Geophys. Res. Lett. 2007, 34, L14813. [CrossRef]

6. Fueglistaler, S.; Dessler, A.E.; Dunkerton, T.J.; Folkins, I.; Fu, Q.; Mote, P.W. Tropical tropopause layer. Rev. Geophys. 2009, 47, RG1004. [CrossRef]

7. Solomon, S.; Rosenlof, K.H.; Portmann, R.W.; Daniel, J.S.; Davis, S.M.; Sanford, T.J.; Plattner, G.K. Contributions of stratospheric water vapor to decadal changes in the rate of global warming. Science 2010, 327, 1219-1223. [CrossRef] [PubMed]

8. Dessler, A.E.; Schoeberl, M.R.; Wang, T.; Davis, S.M.; Rosenlof, K.H. Stratospheric water vapor feedback. Proc. Natl. Acad. Sci. USA 2013, 110, 18087-18091. [CrossRef] [PubMed]

9. Randel, W.J.; Jensen, E.J. Physical processes in the tropical tropopause layer and their roles in a changing climate. Nat. Geosci. 2013, 6, 169-176. [CrossRef] 
10. Brewer, A.W. Evidence for a world circulation provided by the measurements of helium and water vapour distribution in the stratosphere. Q. J. R. Meteorol. Soc. 1949, 75, 351-363. [CrossRef]

11. Holton, J.R.; Haynes, P.H.; McIntyre, M.E.; Douglass, A.R.; Rood, R.B.; Pfister, L. Stratosphere-troposphere exchange. Rev. Geophys. 1995, 33, 403. [CrossRef]

12. Fueglistaler, S.; Haynes, P.H. Control of interannual and longer-term variability of stratospheric water vapor. J. Geophys. Res. 2005, 110, D24108. [CrossRef]

13. Ding, Q.; Fu, Q. A warming tropical central Pacific dries the lower stratosphere. Clim. Dyn. 2018, 50, 2813-2827. [CrossRef]

14. Thuburn, J.; Craig, G.C. On the temperature structure of the tropical substratosphere. J. Geophys. Res. 2002, 107, 4017. [CrossRef]

15. Birner, T. Residual Circulation and Tropopause Structure. J. Atmos. Sci. 2010, 67, 2582-2600. [CrossRef]

16. Birner, T.; Charlesworth, E.J. On the relative importance of radiative and dynamical heating for tropical tropopause temperatures. J. Geophys. Res. Atmos. 2017, 122, 6782-6797. [CrossRef]

17. Sinha, A.; Shine, K.P. A One-Dimensional study of possible cirrus cloud feedbacks. J. Clim. 1994, 7, $158-173$. [CrossRef]

18. Thuburn, J.; Craig, G.C. Stratospheric influence on tropopause height: The radiative constraint. J. Atmos. Sci. 2000, 57, 17-28. [CrossRef]

19. Corti, T.; Luo, B.P.; Peter, T.; Vömel, H.; Fu, Q. Mean radiative energy balance and vertical mass fluxes in the equatorial upper troposphere and lower stratosphere. Geophys. Res. Lett. 2005, 32, L06802. [CrossRef]

20. Corti, T.; Luo, B.P.; Fu, Q.; Vömel, H.; Peter, T. The impact of cirrus clouds on tropical troposphere-to-stratosphere transport. Atmos. Chem. Phys. 2006, 6, 2539-2547. [CrossRef]

21. Yang, Q.; Fu, Q.; Hu, Y. Radiative impacts of clouds in the tropical tropopause layer. J. Geophys. Res. 2010, 115, D00H12. [CrossRef]

22. Lin, L.; Fu, Q.; Zhang, H.; Su, J.; Yang, Q.; Sun, Z. Upward mass fluxes in tropical upper troposphere and lower stratosphere derived from radiative transfer calculations. J. Quant. Spectrosc. Radiat. Transf. 2013, 117, 114-122. [CrossRef]

23. Winker, D.M.; Hunt, W.H.; McGill, M.J. Initial performance assessment of CALIOP. Geophys. Res. Lett. 2007, 34, L19803. [CrossRef]

24. Winker, D.M.; Pelon, J.; Coakley, J.A.; Ackerman, S.A.; Charlson, R.J.; Colarco, P.R.; Flamant, P.; Fu, Q.; Hoff, R.M.; Kittaka, C.; et al. The CALIPSO mission: A global 3D view of aerosols and clouds. Bull. Am. Meteorol. Soc. 2010, 91, 1211-1229. [CrossRef]

25. Tseng, H.H.; Fu, Q. Tropical tropopause layer cirrus and its relation to tropopause. J. Quant. Spectrosc. Radiat. Transf. 2017, 188, 118-131. [CrossRef]

26. Austin, R.T.; Heymsfield, A.J.; Stephens, G.L. Retrieval of ice cloud microphysical parameters using the CloudSat millimeter-wave radar and temperature. J. Geophys. Res. 2009, 114, D00A23. [CrossRef]

27. King, M.D.; Platnick, S.; Menzel, W.P.; Ackerman, S.A.; Hubanks, P.A. spatial and temporal distribution of clouds observed by MODIS onboard the terra and aqua satellites. IEEE Trans. Geosci. Remote Sens. 2013, 51, 3826-3852. [CrossRef]

28. Heymsfield, A.; Winker, D.; Avery, M.; Vaughan, M.; Diskin, G.; Deng, M.; Mitev, V.; Matthey, R. Relationships between ice water content and volume extinction coefficient from in situ observations for temperatures from $0^{\circ} \mathrm{C}$ to $-86^{\circ} \mathrm{C}$ : Implications for spaceborne lidar retrievals. J. Appl. Meteorol. Climatol. 2014, 53, 479-505. [CrossRef]

29. Fueglistaler, S.; Fu, Q. Impact of clouds on radiative heating rates in the tropical lower stratosphere. J. Geophys. Res. 2006, 111, 23202. [CrossRef]

30. Dee, D.P.; Uppala, S.M.; Simmons, A.J.; Berrisford, P.; Poli, P.; Kobayashi, S.; Andrae, U.; Balmaseda, M.A.; Balsamo, G.; Bauer, P.; et al. The ERA-Interim reanalysis: Configuration and performance of the data assimilation system. Q. J. R. Meteorol. Soc. 2011, 137, 553-597. [CrossRef]

31. Hartmann, D.L.; Holton, J.R.; Fu, Q. The heat balance of the tropical tropopause, cirrus, and stratospheric dehydration. Geophys. Res. Lett. 2001, 28, 1969-1972. [CrossRef]

32. Kursinski, E.R.; Hajj, G.A.; Schofield, J.T.; Linfield, R.P.; Hardy, K.R. Observing Earth's atmosphere with radio occultation measurements using the Global Positioning System. J. Geophys. Res. Atmos. 1997, 102, 23429-23465. [CrossRef] 
33. Kuo, Y.H.; Wee, T.K.; Sokolovskiy, S.; Rocken, C.; Schreiner, W.; Hunt, D.; Anthes, R. Inversion and error estimation of GPS radio occultation data. J. Meteorol. Soc. 2004, 82, 507-531. [CrossRef]

34. Anthes, R.A.; Bernhardt, P.A.; Chen, Y.; Cucurull, L.; Dymond, K.F.; Ector, D.; Healy, S.B.; Ho, S.-P.; Hunt, D.C.; Kuo, Y.-H.; et al. The COSMIC/FORMOSAT-3 mission: Early results. Bull. Am. Meteorol. Soc. 2008, 89, 313-334. [CrossRef]

35. He, W.; Ho, S.; Chen, H.; Zhou, X.; Hunt, D.; Kuo, Y.H. Assessment of radiosonde temperature measurements in the upper troposphere and lower stratosphere using COSMIC radio occultation data. Geophys. Res. Lett. 2009, 36, L17807. [CrossRef]

36. Wang, B.R.; Liu, X.Y.; Wang, J.K. Assessment of COSMIC radio occultation retrieval product using global radiosonde data. Atmos. Meas. Tech. 2013, 6, 1073-1083. [CrossRef]

37. Kishore, P.; Namboothiri, S.P.; Jiang, J.H.; Sivakumar, V.; Igarashi, K. Global temperature estimates in the troposphere and stratosphere: A validation study of COSMIC/FORMOSAT-3 measurements. Atmos. Chem. Phys. 2009, 9, 897-908. [CrossRef]

38. Fu, Q.; Liou, K.N. On the correlated $k$-Distribution method for radiative transfer in Nonhomogeneous Atmospheres. J. Atmos. Sci. 1992, 49, 2139-2156. [CrossRef]

39. Fu, Q.; Liou, K.N. Parameterization of the radiative properties of cirrus clouds. J. Atmos. Sci. 1993, 50, 2008-2025. [CrossRef]

40. $\mathrm{Fu}, \mathrm{Q}$. An accurate parameterization of the solar radiative properties of cirrus clouds for climate models. J. Clim. 1996, 9, 2058-2082. [CrossRef]

41. Fu, Q.; Liou, K.N.; Cribb, M.C.; Charlock, T.P.; Grossman, A. Multiple scattering parameterization in thermal infrared radiative transfer. J. Atmos. Sci. 1997, 54, 2799-2812. [CrossRef]

42. Fu, Q.; Yang, P.; Sun, W.B. An accurate parameterization of the infrared radiative properties of cirrus clouds for climate models. J. Clim. 1998, 11, 2223-2237. [CrossRef]

43. Kratz, D.P.; Rose, F.G. Accounting for molecular absorption within the spectral range of the CERES window channel. J. Quant. Spectrosc. Radiat. Transf. 1999, 61, 83-95. [CrossRef]

44. Rose, F.; Charlock, T.P. New Fu-Liou code tested with ARM raman lidar and CERES in pre-CALIPSO exercise. In Proceedings of the 11th Conference on Atmospheric Radiation, Odgen, UT, USA, 3 June 2002.

45. Fu, Q. A new parameterization of an asymmetry factor of cirrus clouds for climate models. J. Atmos. Sci. 2007, 64, 4140-4150. [CrossRef]

46. Liou, K.N.; Fu, Q.; Ackerman, T.P. A simple formulation of the Delta-Four-Stream approximation for radiative transfer parameterizations. J. Atmos. Sci. 1988, 45, 1940-1948. [CrossRef]

47. Tobin, D.C.; Best, F.A.; Brown, P.D.; Clough, S.A.; Dedecker, R.G.; Ellingson, R.G.; Garcia, R.K.; Howell, H.B.; Knuteson, R.O.; Mlawer, E.J. Downwelling spectral radiance observations at the SHEBA ice station: Water vapor continuum measurements from 17 to $26 \mu \mathrm{m}$. J. Geophys. Res. Atmos. 1999, 104, 2081-2092. [CrossRef]

48. Johnson, R.H.; Rickenbach, T.M.; Rutledge, S.A.; Ciesielski, P.E.; Schubert, W.H. Trimodal characteristics of tropical convection. J. Clim. 1999, 12, 2397-2418. [CrossRef]

49. Haynes, J.M.; Stephens, G.L. Tropical oceanic cloudiness and the incidence of precipitation: Early results from CloudSat. Geophys. Res. Lett. 2007, 34. [CrossRef]

50. Su, H.; Jiang, J.H.; Vane, D.G.; Stephens, G.L. Observed vertical structure of tropical oceanic clouds sorted in large-scale regimes. Geophys. Res. Lett. 2008, 35, L24704. [CrossRef]

51. Fu, Q. Bottom up in the tropics. Nat. Clim. Chang. 2013, 3, 957-958. [CrossRef]

52. Tseng, H.H.; Fu, Q. Temperature control of the variability of tropical tropopause layer cirrus clouds. J. Geophys. Res. Atmos. 2017, 122, 11062-11075. [CrossRef]

53. Morcrette, J.J. Impact of changes to the radiation transfer parameterizations plus cloud optical. properties in the ECMWF model. Mon. Weather Rev. 1990, 118, 847-873. [CrossRef]

54. Zhong, W.; Haigh, J.D. Improved broadband emissivity parameterization for water vapor cooling rate calculations. J. Atmos. Sci. 1995, 52, 124-138. [CrossRef]

55. Zhong, W.; Toumi, R.; Haigh, J.D. Climate forcing by stratospheric ozone depletion calculated from observed temperature trends. Geophys. Res. Lett. 1996, 23, 3183-3186. [CrossRef]

56. Mlawer, E.J.; Taubman, S.J.; Brown, P.D.; Iacono, M.J.; Clough, S.A. Radiative transfer for inhomogeneous atmospheres: RRTM, a validated correlated-k model for the longwave. J. Geophys. Res. Atmos. 1997, 102, 16663-16682. [CrossRef] 
57. Iacono, M.J.; Mlawer, E.J.; Clough, S.A.; Morcrette, J.J. Impact of an improved longwave radiation model, RRTM, on the energy budget and thermodynamic properties of the NCAR community climate model, CCM3. J. Geophys. Res. Atmos. 2000, 105, 14873-14890. [CrossRef]

58. Yang, Q.; Fu, Q.; Austin, J.; Gettelman, A.; Li, F.; Vömel, H. Observationally derived and general circulation model simulated tropical stratospheric upward mass fluxes. J. Geophys. Res. 2008, 113, D00B07. [CrossRef]

59. Thompson, A.M.; Witte, J.C.; Smit, H.G.J.; Oltmans, S.J.; Johnson, B.J.; Kirchhoff, V.W.J.H.; Schmidlin, F.J. Southern Hemisphere Additional Ozonesondes (SHADOZ) 1998-2004 tropical ozone climatology: 3. Instrumentation, station-to-station variability, and evaluation with simulated flight profiles. J. Geophys. Res. 2007, 112, D03304. [CrossRef]

60. Russell, J.M.; Gordley, L.L.; Park, J.H.; Drayson, S.R.; Hesketh, W.D.; Cicerone, R.J.; Tuck, A.F.; Frederick, J.E.; Harries, J.E.; Crutzen, P.J. The halogen occultation experiment. J. Geophys. Res. 1993, 98, 10777. [CrossRef]

61. McClatchey, R.A.; Fenn, R.W.; Selby, J.E.A.; Volz, F.E.; Garing, J.S. Optical Properties of the Atmosphere; Air Force Rep. AFCRL-71-0279; Air Force Geophysics Laboratory: Bedford, MA, USA, 1971.

62. Dinh, T.; Fueglistaler, S. Cirrus, transport, and mixing in the tropical upper troposphere. J. Atmos. Sci. 2014, 71, 1339-1352. [CrossRef]

(C) 2018 by the authors. Licensee MDPI, Basel, Switzerland. This article is an open access article distributed under the terms and conditions of the Creative Commons Attribution (CC BY) license (http://creativecommons.org/licenses/by/4.0/). 